HStud 23 (2009)2, 153-173

DOI: 10.1556/HStud.23.2009.2.1

\title{
SURFACE WATER QUALITY IN THE CARPATHIAN BASIN: CURRENT STATUS AND FUTURE DIRECTIONS
}

\author{
KERRY KRUTILLA and KATE LOGAN \\ Indiana University, Bloomington, IN \\ USA
}

\begin{abstract}
This article assesses the current challenges to water management in the Tisza River basin. We overview the environmental characteristics of the Tisza river basin and consider the economic setting within which water policy making must be conducted, before characterizing the principal water pollution sources in the region and assessing water quality monitoring data. We then compare the current status of the region's waters to the normative goals for water quality improvement specified in the European Union Water Framework Directive. Lastly, we assess the future outlook for water quality in the Tisza basin, given the current status of water quality in the region and the prospects for successfully implementing water policy objectives.
\end{abstract}

Keywords: water quality, water-policy, water management, Tisza river, European Union, political transition, flood prevention, channelization

The Tisza river is the main waterway in the Carpathian basin, draining tributaries from a $157,218 \mathrm{~km}^{2}$ area within the countries of Slovakia, Ukraine, Romania, Hungary, and Serbia. The surface area of the Tisza river basin is also the largest catchment of any sub-basin of the Danube River system, accounting for 20 per cent of the Danube's total catchment. Within this expanse are diverse natural landscapes of high ecological value, with many protected areas and national parks (CEO, 2007). The riparian environment of the Tisza river in undeveloped lowland areas contains a significant number of oxbow lakes and wetlands of unique ecological significance (Burnod-Requia, 2004).

Although bountifully endowed, human intervention has extensively impacted the Tisza basin. More than 56 per cent of the total length of the Tisza river, and significant portions of its tributaries, have been artificially modified to control flooding or supply irrigation water (ICPDR, 2008). The river has also been extensively channelized to recover flood plain land for intensive agricultural production, reducing flood plain area from its natural level by over 90 per cent and diminishing natural biodiversity (Sendzimir et al., 2008). Settlement growth, the development of transportation networks, agricultural expansion, and mining and 
forestry activities in upland regions have all contributed to modifying the natural landscapes of the Tisza river basin.

Economic activities in the Tisza river basin place environmental pressures on both surface waters and ground waters. The complex hydrological regime of the Tisza river, which exhibits both frequent flooding and periods of drought, poses flood risks to settlements and impairs agricultural production in flooded and drought stricken areas.

Water policy-making in the Carpathian region is conducted within the context of evolving political and institutional conditions characteristic of transitional economies, and uneven economic development in the region which has widened during the economic transition. The need for cross-border policy coordination and financial commitments increases the challenge of successful water management in the region.

Yet, the countries of the Tisza basin historically have cooperated in the area of environmental management, at least to the extent of signing a number of bilateral and multilateral agreements. ${ }^{1}$ Starting in the mid 1990s the Tisza countries also became involved in European-wide efforts to address water management issues in the Danube river basin. The Tisza countries have signed The Danube River Protection Convention (DRPC), an agreement which provides the framework for water policy formulation in the Danube basin, and coordinate with the International Commission for the Protection of the Danube River (ICPDR) established in 1998, to implement the DRPC. The accession of Hungary and Slovakia to the European Union in 2004 followed by Romania in 2007 also fortuitously coincided with the initial implementation period of the EU Water Framework Directive (EU WFD). The EU WFD rationalizes existing EU policies and directives and fundamentally reorients European water management (Barreira, 2006; Page and Kaika, 2003; Vari et. al., 2009). In the Tisza Basin, the WFD implementation incorporates the pre-existing water management program established in response to the DRPC and makes the ICPDR the responsible entity for oversight and coordination. Under the auspices of the ICPDR, a "Memorandum of Understanding" was signed in 2004 by the five Tisza countries agreeing to formulate a Tisza River Basin Management Plan by the end of 2009 (ICPDR, 2008). Since this management plan is a requirement for the EU member countries as an interim step to implementing the EU WFD, Serbia and Ukraine, the countries in the Tisza basin which are not EU members, have voluntarily brought themselves within the EU policy framework. This development provides a significant push toward integrated regional policy-making and coordinated water management within the Tisza basin.

This article outlines the current challenges to water management in the Tisza River basin, and describes the legal frameworks and policy initiatives undertaken to address them. Although managing water quality and quantity, on the one hand, and hydrological regulation for flood control and irrigation, on the other, are inter- 
connected problems, these issues also pose distinctive policy challenges which are addressed in the Tisza river basin (and throughout the Danube River system) through separate EU Directives and national policies. This article primarily focuses on water management in the Tisza basin distinct from riparian regulation, reserving attention to hydrologic regulation when it is related to water quality management (as in the treatment of hydromorphological modifications within the EU WFD). Within the arena of water management per se, the focus is principally on surface water quality rather than ground water quality or management of the region's water balance. This distinction is not justified by differences in legal status, since the EU WFD now comprehensively incorporates all aspects of water management within one overarching framework. Rather, space constraints motivate the focus on surface water quality as the main topic in this particular article.

The next section turns to an overview of the environmental characteristics of the Tisza river basin to provide some perspective on surface water in the region. The following section considers the economic setting within which water policy making must be conducted, before turning to a characterization of the principal water pollution sources in the Tisza basin. The next task is to review recent water quality monitoring data to assess how the sources of pollution in the Tisza basin impact the status of water quality in the region. Next we describe policy goals and requirements for water management in the Tisza basin, and present an assessment of how the current status of the waters compare to the normative goals for water quality improvement specified in the WFD. The final section of the article concludes with an assessment of the future outlook for water quality in the region, based on assessment of current water status in the Tisza basin and the prospects for successfully implementing the requirements of the WFD.

\section{Environmental Characteristics of the Tisza River Basin}

The natural boundary of the Tisza catchment from the north, east, and southeast is framed by the arc of the Carpathian mountains running through Slovakia, the southwest tip of Ukraine, and into the Transylvanian region of Romania; the Tisza's tributaries originate in this mountainous area (see Map 1). The Tisza river itself begins in Ukraine and flows along the northern border region of Romania for a short distance before again reentering the Ukraine and then flowing into Hungary. After a bend to the north the river reaches a region in the area of the border of Hungary and Slovakia, before making a U-turn to the southwest, subsequently coursing in a generally southerly direction through the great Hungarian plain. Along its journey, the Tisza accumulates waters from major eastern tributaries originating in the Transylvanian region of Romania as well as northern tributaries originating in the Slovak Republic (again see Map 1). In its final stage, the 


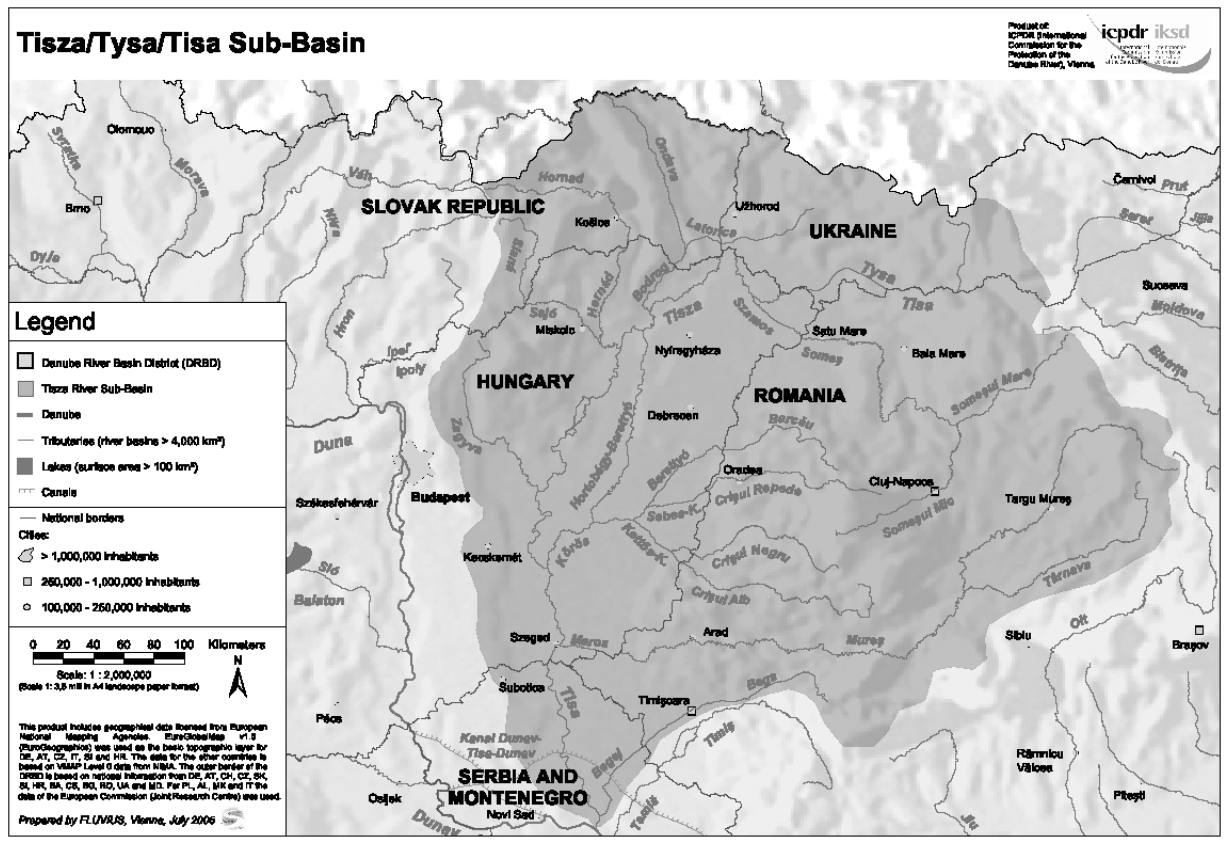

Map 1

Tisza enters Serbian territory a short distance south of Szeged, Hungary, finally joining the Danube river about 45 kilometers upstream of Belgrade.

The Tisza river is usually divided into three segments: "The Upper Tisza", running through parts of Ukraine, Romania and Hungarian territory north of the Szamos river confluence; "The Middle Tisza," lying entirely in Hungary, running from the Szamos river confluence to the Maros river confluence at Szeged, and the "Lower Tisza," the portion of the river south of Szeged, the majority of which lies in Serbia. ${ }^{2}$ The total present-day length of the Tisza is 966 kilometers, with 70 per cent of this distance lying south of the Ukraine-Hungarian border. The Serbian portion of the Tisza measures 166 kilometers (Saken et al., 2002).

After leaving the upland region of the Carpathians, the velocity of the Tisza's water flow drops significantly. Before the mid 19th century, the lower elevation stretch of the Middle Tisza was characterized by abundant river meanders, oxbow lakes, wetlands and large floodplains (Vujanovic et al., 2002). Starting in the mid 19th century, the river was extensively modified in attempt to control flooding and to allow floodplains to be drained and converted into agricultural lands. Extensive channelization eliminated many meanders, reducing the present day length of the river to 70 per cent of its original, in the process severely reducing the degree of hydrological connectivity along the river (ICPDR, 2008). The construction of dikes, levees, weirs, and reservoirs along the Tisza have heavily mod- 
ified the flow of the river, its embankments, and the natural environment around it. Wetlands and natural biodiversity have been significantly supplanted in the region through agricultural expansion and the introduction of nonnative invasive species (Sendzimir et al., 2008).

Seasonal flooding incidents are historically a major problem along the Middle Tisza and have increased in frequency in the past decade (Burnod-Requia, 2004). The regulation of the Tisza, while allowing floodplain to be recovered for agricultural land, has exacerbated flooding problems to the south. The elimination of meanders and wetlands reduced the capacity of the river to attenuate rising flood waters caused by heavy precipitation or snow melt in the upland region of the Carpathian basin. Rain events in the Carpathians can cause the Tisza river in the lower reaches to rise more than twelve meters within 24 hours. Riparian defensive infrastructure has proved inadequate to contain water surges of this magnitude, leading to catastrophic flooding of riparian communities such as Szolnok and Szeged, and damage to agricultural lands (Sendzimir et al., 2008).

\section{Economic Conditions}

The upper catchment area of the Tisza basin in the Carpathian mountains is forested with mostly deciduous trees, and timber production and wood processing is important to local economies in this region, particularly in Slovakia and Ukraine. There is also a cellulose and paper industry in the Upper Tisza River Basin in the Slovak Republic. The mining of nonferrous metals is an important economic activity in Romania, with mining operations concentrated in the region around the Maramureš and Guti Mountains in the Someš sub-basin and the Apuseni Mountains in the sub-basin drained by the Mures river. Heavy manufacturing, including chemicals, petrochemicals, and metallurgy, is located in the Middle and Upper Tisza region and in the Prešov region of southeastern Slovakia. The lowland areas of the basin are used extensively for agriculture. The food industry is located in the Middle Tisza, although it is also a locally important sector in other regions of the Tisza basin (Burnod-Requia, 2004).

Economies throughout eastern Europe faced difficult adjustments in the post Soviet transitional era, associated with the restructuring of state-owned enterprises, the reduction of subsidies to industry and agriculture, the collapse of preexisting trade networks within the Soviet block, and competition from western European firms (Lackenbauer, 2004, Sendzimir, 2008, CEO, 2007). Manufacturing and agricultural output declined sharply throughout the region in the early in 1990s inducing long recessions in all of the Tisza countries. Per capita GDP did not again reach its 1989 level in the Slovak Republic and Hungary until about 1999, and in Romania until 2003 (CEO, 2007). As of 2005, per capita output in 
The Ukraine was still 60 per cent of its 1989 level. Economic development of the Tisza countries remains comparatively low, with the per capita GDPs of Hungary and Slovakia roughly 60 per cent of the EU-25 average in 2002, and Romania at around one third of the EU-25 average (Lackenbauer, 2004). The per capita GDP in Ukraine and Serbia are lower than the other countries of the Carpathian basin. ${ }^{3}$

Country-level GDP trends are only partially indicative of the economic status of the Tisza basin itself, however, masking the selective pattern and geographic incidence of economic change during the transition period, and the selective nature of the recovery in the period since 2000. In fact, the economy of the Tisza basin is undergoing a long standing economic decline. Inefficient industrial plants in the region, and large scale agricultural enterprises, have been hit hard by the transition, and economic activity in the large rural portion of the basin has become increasingly marginalized into small farms and the informal economy, with significant outmigration of working age populations (CEO, 2007). The hydrological regime of the Tisza contributes to the economic problem along the Middle Tisza, with floods and standing water diminishing production during the autumn and spring months, and drought conditions diminishing agricultural output during the summer (Vari et al., 2009). Flood risks to streamside communities along much of the Tisza creates feelings of uncertainty which reinforce the negative psychological effects of the economic downturn, and flood events impose large economic costs for recovery (Sendzimir et al., 2008). Diminishing economies and populations reduce resources for infrastructure investments and public services, typical of regions in economic decline.

Not surprisingly, the economic statistics from the Tisza basin are generally lower than the country-level averages of the countries which form it. Unemployment in the Upper Tisza region of Hungary is twice as high as the country average (Vari et al., 2009), employment in low paying jobs like agriculture throughout the Hungarian Tisza region is five times higher than national averages, and the rate of outmigration from Tisza countries 50 per cent higher than other counties in Hungary (Sendzimir et al., 2008). The per capita income of the Észak-Alföld (Northern Great Plain) region of Hungary is about 64 per cent of the average for Hungary and about 38 per cent of the average for the EU-25 (EU, 2009). The per capita GDP in this region, however, is still around twice as high as in the poorest sections of the Tisza basin in parts of the central and southern Carpathians in Romania, and in eastern Serbia in the southern most part of the Tisza river basin (CEO, 2007). In general, economic transition has widened the pre-existing regional disparities which existed between the Tisza basin and the more developed sections of the countries which form it. ${ }^{4}$ 


\section{Environmental Effects of Transition}

Historically, large collectivized enterprises in the region imposed significant costs to the environment and human health, reflecting the concentration of large industry in mining and manufacturing settlements, and inadequate enforcement of environmental laws by relatively weak environmental ministries (Pickvance, 2002). In the upland regions of the Tisza basin, forests were clearcut and harvested at a higher-than-sustainable rate, diminishing forest stocks and natural habitats, and increasing the risk of landslides, soil erosion, and water sedimentation (CEO, 2007). Large scale farm collectivization and agricultural land conversion in the lowland regions during the 1960s transformed natural landscapes and increased the rate of agricultural water pollution. Inadequately-controlled waste water discharges from large industrial facilities and nonferrous mining and ore processing also contributed to water pollution.

Economic transformation in the Tisza region has had mixed effects on the driving forces causing water pollution. Some sources of pollution are closely linked to the level of production, such as industrial wastewater discharges, and agricultural sources of chemical, pesticide, nutrient, and organic waste effluents. The absolute level of pollution from these kinds of sources has probably declined since 1989 more or less proportionately to the economic contraction in the Tisza basin. The intensity of water pollution from industrial plants in the Tisza basin during the Soviet period was probably significantly higher than their Western European counterparts, so currently-operating plants dating from the pre-transition period are still generating relatively high pollution loadings on a per unit of output basis. ${ }^{5}$ However, even in the Middle Tisza agricultural region, the intensity of agricultural input use, such as the use of fertilizer and pesticides was lower in Soviet times than in Western Europe for all but a brief period in the late 1980s (Kerekes and Kiss, 1998). Given both the absolute decline in the agricultural sector and the reduced intensivity of non-labor input use during the transition period, it seems quite likely that both the absolute burden and relative intensity of water pollution from agriculture in the region are now significantly lower than before, and lower than in the main agricultural regions of Western Europe, such as in the Hase river catchment in Lower Saxony, Germany (Kastens and Newig, 2007).

For the three EU countries in the Tisza basin, financial support received from the European Union is a second reason for some environmental improvement in the transition period. During the pre-accession phase, PHARE funds were used to finance environmental infrastructure such as sewage treatment (Pickvance, 2002), and after 2000 the ISPA fund has been used to finance environmental projects. The Cohesion Fund is available to finance environmental infrastructure in the EU countries in the Tisza basin now that they are EU members. 
On the other side of the ledger, the negative socioeconomic trends associated with the deteriorating regional economy have likely added environmental pressures in the region (CEO, 2007). Local funding for infrastructure investments in sewage treatment has declined and maintenance procedures and management practices for municipal and industrial landfills have weakened, increasing water pollution risks from water runoff. Lack of funding from the national level before 2015-20 for small settlements below 2000 inhabitants makes this a particular problem in rural areas (Vari et al., 2009). The rise of the informal economy has reportedly increased illegal forest cutting for woodfuels and local products, further eroding lands in the upland region of the basin, with attendant negative effects on water quality (CEO, 2007). Of course, it is more difficult to regulate the actions of actors in the informal economy for any reason, including environmental protection.

Beyond new environmental pressures linked to changing socioeconomic conditions are the legacy effects of the old system. They include the continued existence of older inefficient industrial facilities with inadequate pollution controls, the problems of acid drainage from existing and abandoned mine sites, and risk of accidental release of chemicals from "industrial hotspots" throughout the region.

\section{Pollution Sources}

To better gauge the causes and impacts of the countervailing forces impacting surface water quality in the Tisza river basin in the recent transitional period, we turn to a more detailed characterization of the pollution sources in the region, and the monitoring data on ambient water quality of the Tisza and its tributaries. Preliminary data are available from ongoing interim assessments and monitoring actions taken as part of the implementation plan for the EU WFD.

Water pollution sources can be categorized along two dimensions. The first distinction is between point and diffuse sources. Point sources are large emitters whose discharge volumes are localized and substantial enough to be easily detected and monitored. They include municipal sewage treatment plants, industrial facilities, and large-scale agricultural enterprises. Diffuse sources, in contrast, are smaller more dispersed and less easily observed and monitored dischargers, including small farms, home or small scale industry in the informal sector, and residents in small towns and rural areas whose waste discharges may be directly released to the environment without treatment.

The second distinction is between pollution sources from which effluent discharges are directly linked to production or consumption - typically municipal sewage treatment plants, or industrial and agricultural sources - and sources from which pollution is released over time as a result of water percolation through inad- 
equately-contained solid waste stockpiles, which remain long after the consumption and production activity which generated them has ceased.

An overview of the distribution of point sources among sectors and countries in the Tisza basin is indicated in Table 1. An inventory of the largest point source emitters in the Tisza basin shows a total of 51 municipal facilities, 39 industrial, and 2 agricultural sources discharging into the region's waterways. The majority of these sources are located in Romania (see Table 2).

Table 1

Distribution of Water Pollution Point Sources in the Tisza Basin

\begin{tabular}{lccccc}
\hline $\begin{array}{l}\text { Water Pollutant } \\
\text { Sources }\end{array}$ & Ukraine & Slovakia & Romania & Hungary & Serbia \\
\hline Mining & & $\mathrm{X}$ & $\mathrm{X}$ & $\mathrm{X}$ & \\
Agriculture & & $\mathrm{X}$ & $\mathrm{X}$ & $\mathrm{X}$ & $\mathrm{X}$ \\
Chemicals & & $\mathrm{X}$ & $\mathrm{X}$ & $\mathrm{X}$ \\
Food & & $\mathrm{X}$ & & $\mathrm{X}$ \\
Municipal Sewage & & $\mathrm{X}$ & & $\mathrm{X}$ & $\mathrm{X}$ \\
Energy & & $\mathrm{X}$ & & $\mathrm{X}$ & \\
Machinery & & $\mathrm{X}$ & $\mathrm{X}$ & $\mathrm{X}$ & \\
Pharmacy & $\mathrm{X}$ & $\mathrm{X}$ & $\mathrm{X}$ & $\mathrm{X}$ \\
Pulp and Paper & $\mathrm{X}$ & $\mathrm{X}$ & $\mathrm{X}$ & & $\mathrm{X}$ \\
Oil & $\mathrm{X}$ & & $\mathrm{X}$ & $\mathrm{X}$ & $\mathrm{X}$ \\
Metallurgy & & & & \\
Municipal WWTP & & & & \\
\hline Source: BurnolReguial
\end{tabular}

Source: Burnod-Requia (2004).

Table 2

Significant Pressures (Point Sources) in the Tisza River Basin

\begin{tabular}{lccc}
\hline Countries & Municipal & Industrial & Agricultural \\
\hline Ukraine & 1 & 0 & 0 \\
Romania & 22 & 25 & 2 \\
Slovak Republic & 1 & 1 & 0 \\
Hungary & 11 & 7 & 0 \\
Serbia* & 16 & 6 & 0 \\
Total & 51 & 39 & 2 \\
\hline
\end{tabular}

* Municipal and industrial point sources discharges for Tisza River Basin in Serbia are only estimated

Source: ICPDR (2008).

The distribution of diffuse effluent sources is more difficult to observe and monitor, but diffuse source water emitters often come from forestry operations and agricultural producers. Pollution sources include sediment loadings associated with poorly-managed agricultural and forestry activities, and agrochemical 
runoff and organic waste water from farms and livestock operations. Improper sewage treatment in small settlements and rural areas of the basin also contributes to water pollution.

A significant cause of both point and diffuse source water pollution in the Tisza basin stems from inadequate waste management procedures, both a legacy of the past, and a continuing problem. Water pollution problems are generated by improperly handled non-hazardous municipal solid wastes as well as industrial landfills, which may contain toxic compounds. The storage of hazardous chemicals, including spent industrial solvents and obsolete pesticides is of concern throughout the Tisza basin. Currently there is no comprehensive inventory of such sites in the region (ICPDR, 2008).

A public opinion survey conducted in Szabolcs-Szatmár-Bereg county in the northeast corner of Hungary provides an interesting indication of the perception of residents in this largely rural region about the relative importance of different pollution sources there. The most significant sources, flagged by roughly $1 / 3$ of the respondents, were the runoff of agricultural chemicals and fertilizers, unprofessional operation of household septic tanks, and waste water discharges from households into surface water. Waste water discharges from industrial emitters were seen as significant by about 24 per cent of the respondents. ${ }^{6}$ Although public opinion may not correspond to professional analysis, and generalizations from one study and one region must be offered cautiously, these results might be taken as suggestive of the kinds of pollution sources found in at least some of the rural areas in the Upper Tisza region of Hungary.

The contribution of non-ferrous metal mining to water pollution in the Tisza basin deserves mention. The sources of water pollution from nonferrous mining are several. The initial extraction of ores generates large piles of residual rock materials which often contain sulfide-bearing compounds. The exposure of sulfide compounds in slag heaps to air enables the oxidization of sulfides into sulfuric acid. Acid runoff from slag heaps has direct environmental effects by altering the $\mathrm{pH}$ balance of receiving waters, but acidic mine drainage also leaches common heavy metals such as copper, zinc, selenium, cadmium, mercury, and arsenic (ICPDR, 2008). Water percolating through piles of waste rock can generate toxic, acidified effluents for decades after mines are closed and abandoned. Even when such sites are located, establishing ownership or responsible parties for liability assessment can be difficult. Controlling water contamination from abandoned mine sites is currently a significant problem in the Somes and Mures upland tributary region of the basin where mining operations are concentrated (BurnodRequia, 2004).

Another step in the mining process is to crush and pulverize extracted raw ores, so the valuable fraction can be physically and/or chemically separated from the less valuable "tailings." The direct discharge of slurry effluents containing tail- 
ings sludge contaminated with heavy metals and toxic chemical solvents, such as cyanide (used in gold processing operations), pose a significant water pollution risk. Often slurry mixtures with tailings sludge are stored in ponds or impoundments. As of 2001, for example, there were 215 tailings impoundments in Maramures county (in the Somes sub-basin) storing tailings produced from seven major mining sites (Lucas, 2001). Seepage or runoff from tailings pounds can be a significant source of water pollution.

If tailing impoundments are not structurally stable, there is a risk of a catastrophic breach and the large volume release of toxic slurries. Two tailings ponds ruptures occurred in Maramures county in January and March of 2000. Heavy rains and snow melt caused the failure of an impoundment near Baia Mare, Romania, releasing approximately $100,000 \mathrm{~m}^{3}$ of cyanide and heavy metal-rich wastewater which ended up in the Lapus river, a tributary of the Somes river. A plume of cyanide-contaminated water moved slowly downstream, taking 14 days to reach the Hungarian/Serbian border before continuing to the Danube river (UNEP/OCHA, 2000). Phyto- and zooplankton populations were killed off from

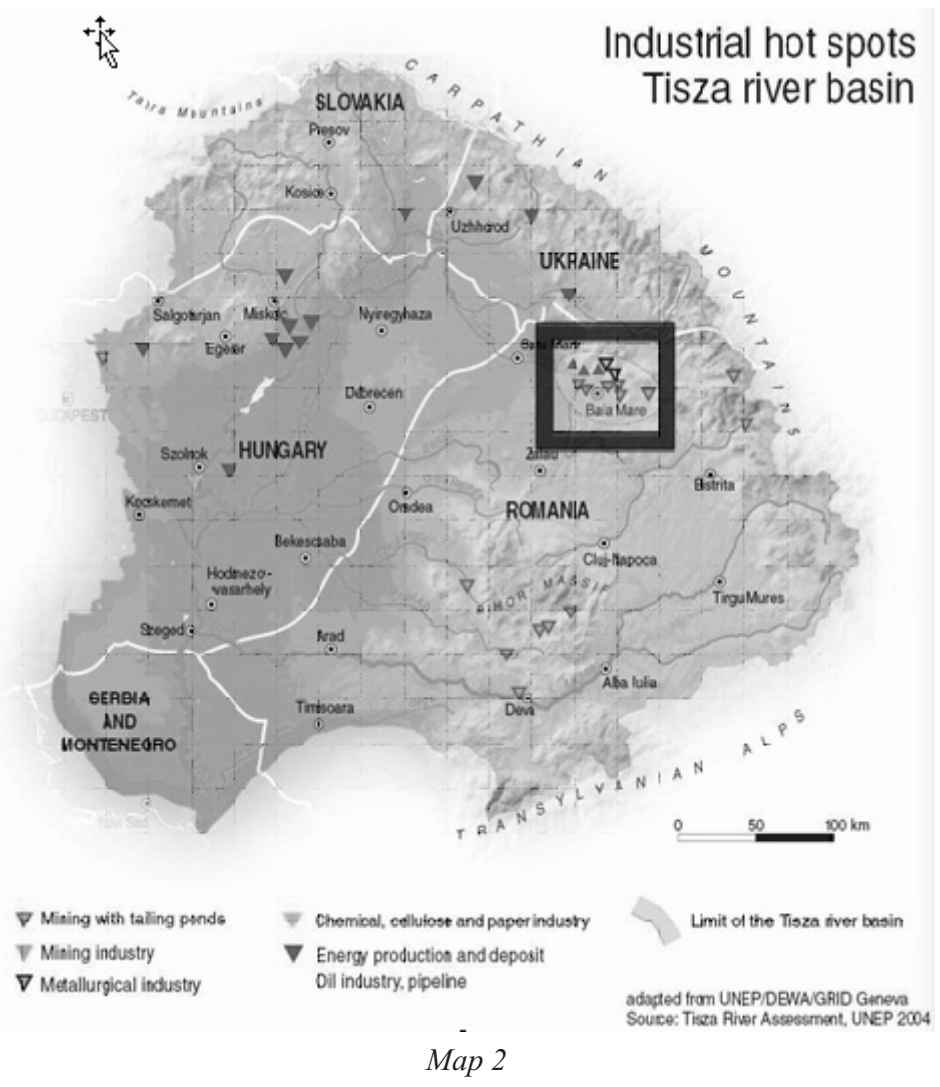


acute cyanide poisoning during or immediately after the episode (Lucas, 2001), and major fish kills were reported. Although cyanide quickly disperses and does not accumulate in the biological system (Lucas, 2001), limited baseline data made an adequate ecological impact assessment difficult (Sendzimir et al., 2008).

A little over a month later a similar incident occurred at a tailings impoundment near Baia Borsa in the same county. Heavy rains and snowmelt caused an overflow and subsequent breech of the dam, spilling $100,000 \mathrm{~m}^{3}$ of waste water and 20,000 tons of tailings sludge contaminated with heavy metals. A portion of the sludge ended up contaminating local waters, while the waste water ended up in the Viseu river before flowing into the Upper Tisza (Lucas, 2001).

As a result of these accidents, the Tisza countries with support from the EU and international agencies have inventoried at-risk tailings ponds and other "industrial hotspots" in the Tisza basin posing major risks to human health and the environment, and developed an emergency warning and response system. The industrial hotspots in the region with the potential to impact the Tisza river system are significantly concentrated in the mining regions of Romania, and in industrial areas in the Košice and Prešov regions of Slovakia. Some facilities are located in the upper end of the Middle Tisza in Hungary (see Map 2).

\section{Water Quality Monitoring Data}

Surface water quality is commonly measured by a set of standard parameters reflecting the chemical and biological or ecological status of waters. Table 3 shows some common parameters and how their ranges correspond to water quality classes as defined in reports in connection with the Transnational Monitoring Network (TNMN), a Danube basin-wide monitoring network developed by the ICPDR. Water quality parameters can generally be divided into three or four categories. Shown first in Table 3 are the parameters affecting the oxygen content of receiving waters, typically related to organic waste effluents from sewage treatment plants, farms, and some industrial enterprises (like food processing). The oxygen content of water bodies is an important parameter affecting the biological and ecological integrity of the system. Dissolved oxygen concentration (DO) is a direct measure of the oxygen content of water, while various BOD and COD measures show the potential for organic wastes to deplete oxygen in the water through bacterial or chemical breakdown. To provide some perspective on the classification scheme in Table 3, the vast majority of fish species can tolerate DO concentrations of $6 \mathrm{mg} / \mathrm{l}$ or above - the DO content of waters at Class II or above - and begin to have problems at $5 \mathrm{mg} / 1$ (Class III water). DO concentrations of $4 \mathrm{mg} / \mathrm{l}$

will kill almost all fish species. ${ }^{7}$ A second group of parameters measures the concentrations of inorganic compounds of nitrogen and phosphorus (also listed under 
SURFACE WATER QUALITY IN THE CARPATHIAN BASIN

Table 3

Water Quality Classification Used for TNMN purposes

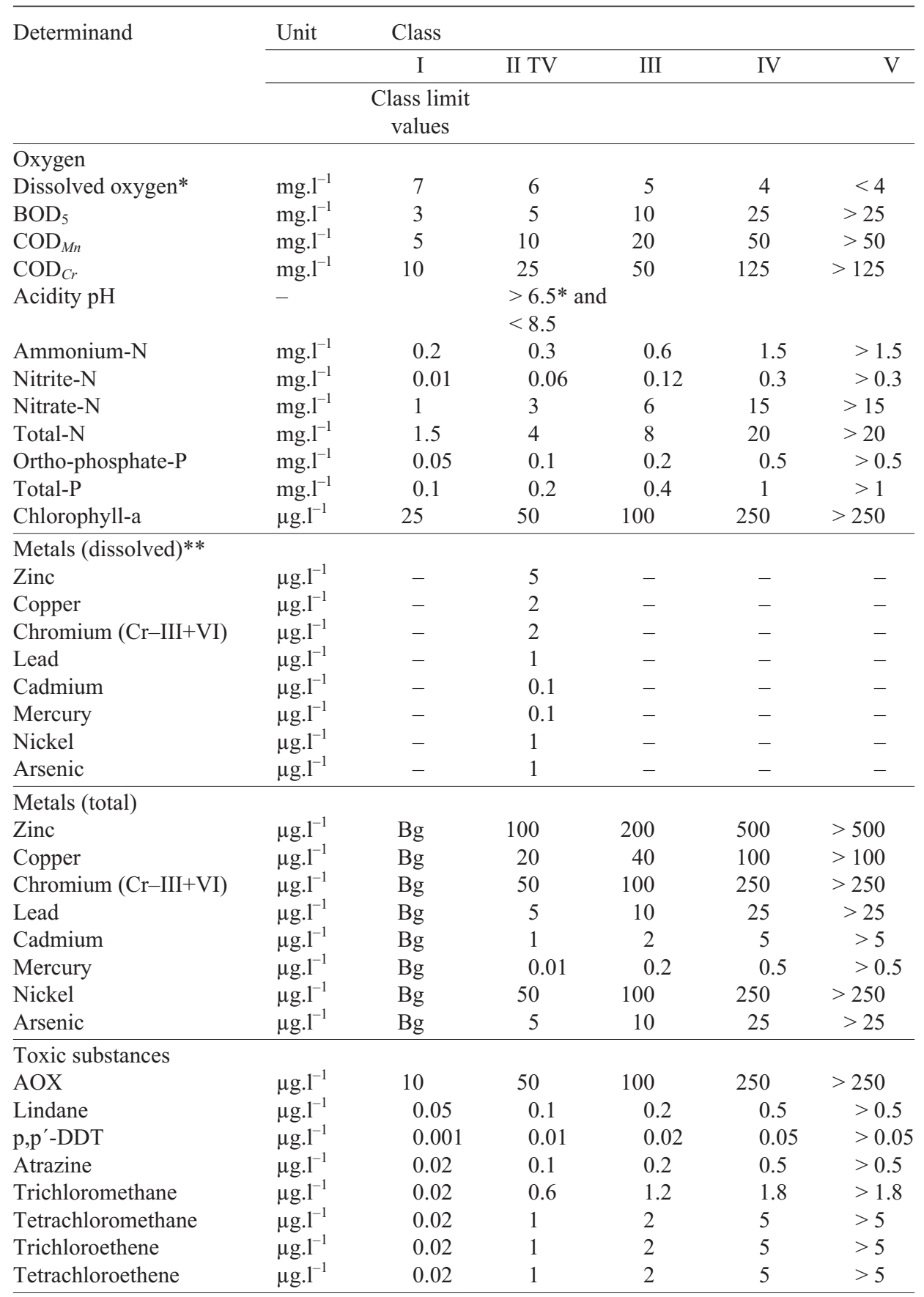


Table 3 (cont.)

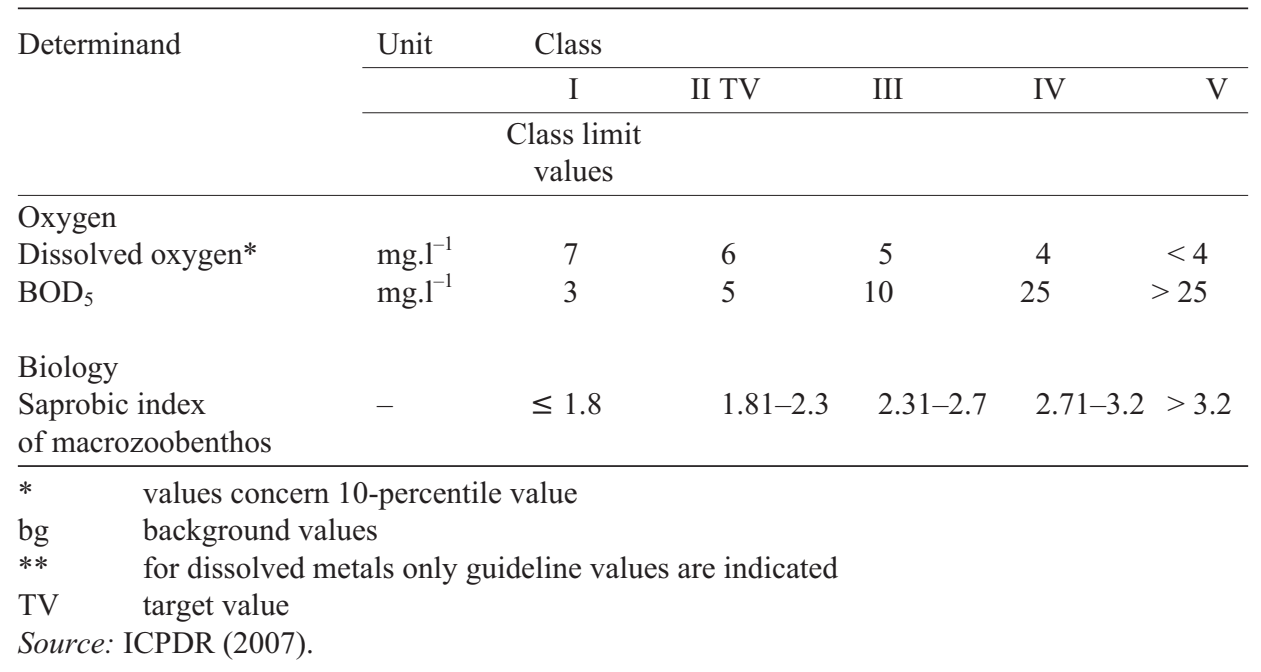

Oxygen in Table 3). Such compounds are usually produced by fertilizer runoff from agricultural lands and inadequately treated municipal sewage. Their discharge into receiving waters creates "eutrophic" (nutrient rich conditions), fertilizing aquatic plant growth. Ultimately, the decay of this plant growth produces organic wastes which reduce the oxygen content of the water.

The concentrations of various heavy metals released from industrial discharges or mobilized by acidified mine waste waters can pose environmental health risks. Heavy metals like lead, cadmium, mercury and arsenic are quite toxic for aquatic biota.

The final group of parameters in Table 3 relate to toxic organic compounds. Pesticides from agricultural water runoff, and chemical wastes from industrial facilities can contain these kinds of compounds. Some organic compounds can be bio-accumulated in ecosystems, posing a risk to consumers (including humans) at the upper end of the food chain.

For all the parameters in Table 3, the Class I column represents levels which pose no serious environmental risk, with the degree of environmental risk progressively increasing moving to Class $\mathrm{V}-$ a level of pollution risk which will terminate the functioning of all aquatic ecosystems.

Under the auspices of the ICPDR, the Tisza countries have produced interim monitoring data for a subset of the parameters in Table 3 over the period 2001-05. ${ }^{8}$ Data in the form of mean annual averages are derived from five monitoring stations in Serbia and one station in Tiszasziget Hungary (on the border with Serbia) - that is, six stations on the Lower Tisza - plus two Romanian sta- 
tions on the Upper Tisza (as the river enters the country from Ukraine and leaves the country). There are also another eight stations covering Romanian tributaries plus the Sajó river in Hungary. As such, the data are limited, leaving out water quality information on the large middle section of the Tisza river.

The data from the available monitoring stations present a mixed picture of water quality in the Tisza river and its tributaries. Parameters measuring dissolved oxygen and oxygen demand are quite good; they show concentrations at Class I for all monitoring stations for all parameters on the Tisza river in the 2001-03 period, and at Class I for all parameters for 2004-05, except for COD-Mn, which was in Class II. Concentrations in the tributaries are at Class I and Class II, except for one monitoring station on the Someš river in Romania, which showed water quality of Class III.

The various parameters measuring inorganic nutrient loading range between Class I and Class III on the Tisza river, with Class II readings being common. The tributary regions yield somewhat higher readings with more Class III readings on the Someš and Crišul Repede river in Romania, and the Sajó river in Hungary. These results suggest some combination of agricultural practices and inadequate sewage treatment or municipal waste landfilling is generating moderate levels of nutrient water pollution.

There are a large range of parameters measuring various heavy metals (see $\mathrm{Ta}$ ble 3). Most of the monitoring sites on the Tisza river show concentrations in the Class II and Class III range, with exception of lead $(\mathrm{Pb})$ which has concentrations at Class IV at all monitoring stations but one (which showed Class I-II). The same general pattern applies in the tributary regions with some higher concentrations found in some of the mining area in Romania (Class IV and Class V). In sum, the waters of the Tisza and its tributaries appear in most monitored stretches to face moderate contamination from heavy metals, with some stretches better and some stretches worse.

The monitoring data on organic toxic compounds are more limited. Only two parameters were considered, and only one, phenol (which can be toxic to fish), was significant. On the Lower Tisza river, levels of phenol were found to be at the Class III level for all monitoring stations except one which was at Class II. The other parameter (anionic detergent) was of Class I. All of the tributaries showed Class III for phenol.

In summary, the available information suggests a moderate level of water pollution on the Tisza river, with some areas having good water quality status for some parameters, and other areas - the mining regions of the Someš, for example - showing high pollution concentrations from lead and other heavy metals. Again this information is based on partial monitoring of the river system, with no information on the surface water quality of the Middle Tisza. 


\section{Water Policy Goals in the Tisza Region}

To provide some perspective on the implications of the current water quality status in the Tisza basin for future water management, we now consider in more detail the provisions of the EU WFD to which the countries of the Tisza basin are obligated (Slovakia, Hungary, Romania) or committed (Serbia, Ukraine). The EU WFD provides an unprecedented, comprehensive framework for water management on several levels (Barreira, 2006; Kastens and Newig, 2007; Page and Kaika, 2003). The framework reorients the planning unit to the basin level independently of administrative jurisdiction or national boundaries, and integrates water management for both quantity and quality and for both surface and ground waters. It also defines a stringent normative goal for surface water quality - so called "good status." Good status encompasses both chemical and ecological status and appears to approximate a degree of water quality consistent with undisturbed pristine conditions in nature. Good chemical status requires reducing the presence of priority substances and eliminating priority hazardous substances by December 2020. Ecological status is based on hydromorphological, biological, and physico-chemical indicators. Member states must prevent the further deterioration of water bodies designated as "artificial and heavily modified" with the objective to achieve good ecological potential for these waters and good chemical status by 2015 (Barreira, 2006).

Similar to the United States, the WFD institutes a regulatory approach which combines the use of effluent discharge limits and ambient water quality standards (termed "Environmental Quality Standards," or EQS). The WFD also requires pricing water usage at high enough rates to encourage conservation, and there appears to be political momentum for "full cost" pricing consistent with the polluters pay principle, i.e., water charges high enough to cover supply costs plus external environmental damages. Finally, the WFD mandates local public participation in the implementation of water policy, reflecting the view that delegating implementation to the local level and involving impacted stakeholders is most likely to lead to successful results on the ground (Kastens and Newig, 2007). ${ }^{9}$ Along with this approach is a requirement for iterative basin planning in the form of updated management plans every six years. The first cycle of river basin management plans are to be completed by the end of 2009 .

As part of the implementation process, the EU WFD mandates an interim risk assessment of the chance that surface waters in a basin will not have attained "good status" overall by 2015. Such a risk assessment was performed for the Tisza river basin in 2007 (ICPDR, 2008). For the assessment of chemical status, a combined approach was used which considered both effluent discharge rates in comparison with EU effluent standards ("limit values") and the monitoring data discussed previously for organic pollution, hazardous substances, and nutrient pollu- 
tion. To gauge ecological status, expert assessment of the potential impact of hydromorphological modifications on stream ecology was used as a proxy, lacking direct measures of ecological quality in the Tisa Basin Tisza and its tributaries. If "good status" was at risk for any of the criteria, the water body was judged "at risk". If information was not available, the water body was judged as "possibly at risk".

The risk analysis suggests that the majority of the waterways and water bodies in the Tisza river basin are "at risk" or "potentially at risk" of not attaining performance goals. Overall, 69 per cent of the Tisza river was judged at risk or possibly at risk from organic pollution, 65 per cent from nutrient pollution, 92 per cent from hazardous substances, and 100 per cent from hydromorphological alterations (ICPDR, 2008). Table 4 shows the distribution of risk status among the Tisza countries. Not surprisingly, the assessment seems to imply that meeting future environmental performance objectives will become more challenging moving from the upstream to downstream sections of the Tisza river.

Table 4

Risk of Failure to Attain "Good Water Status" by 2015

\begin{tabular}{|c|c|c|c|}
\hline & $\begin{array}{l}\text { Organic/nutrient } \\
\text { pollution }\end{array}$ & $\begin{array}{l}\text { Hazardous } \\
\text { substances }\end{array}$ & $\begin{array}{c}\text { Hydromorphological } \\
\text { Alteration }\end{array}$ \\
\hline Upper Tisza-Ukraine & & & Possibly at risk \\
\hline Upper Tisza-Romania & Possibly at risk & At risk & Possibly at risk \\
\hline Middle Tisza (Hungary) & $\begin{array}{l}\text { Possibly at risk/ } \\
\text { At risk }\end{array}$ & $\begin{array}{l}\text { Possibly at risk/ } \\
\text { At risk }\end{array}$ & $\begin{array}{l}\text { Possibly at risk/ } \\
\text { At risk }\end{array}$ \\
\hline Lower Tisza (mostly Serbia) & At risk & At risk & At risk \\
\hline
\end{tabular}

Source: ICPDR (2008)

Similar results obtain for the tributaries, and for the artificial water bodies on both the Tisza river and its tributaries. The overall picture is one of a difficult challenge to move from the status quo to the ambitious water quality objectives of the EU WFD. However, it should be pointed out that meeting the objectives of the EU WFD will pose varying degrees of challenge for all EU member states. For example, the preliminary risk assessment of the U.K. showed that more than 50 per cent of the surface waters there are at risk of not attaining good status by 2015 .

\section{Future Outlook}

The future status of surface water quality in the Tisza basin remains somewhat ambiguous, depending on the continuing effects of soecioeconomic and economic drivers of water pollution in the region; the cost and feasibility of new man- 
agement initiatives, and the financing available for water pollution control. The stringent requirements of the EU WFD provide a powerful external incentive for improving water quality in the region, and the EU provides funding to help support the development and implementation of water management plans. Moreover, international assistance to reduce the risk of accidental chemical spills in the tributary sub-basins in the Transylvanian region of Romania can be expected to continue. However, external financing is not likely to be sufficient to provide all of the necessary financial resources, and public finances in the region are weak. The EU WFD requires raising water rates to incentivize environmentally-beneficial water conservation and generate funds, but there are political limits to the degree to which water rates can be raised, and current water rates in the Tisza basin are not politically popular (Vari et al., 2009). There are also explicit provisions in the WFD to exempt low income regions from the requirement to raise water rates (Page and Kaika, 2003). Thus, generating the necessary financial resources for accomplishing water policy objectives in the region is likely to pose continuing challenges.

The risk assessment prepared under the interim water management plan for the Tisza basin suggests that there is relatively low probability of compliance with the legal obligations of the WFD by the target 2015 date. However, the history of EU policy-making demonstrates that bargaining to accommodate local circumstances is a routine part of the implementation process (Pickvance, 2002; Kastens and Newig, 2007; Page and Kaika, 2003). This suggests that the de facto risk of noncompliance is actually less than that projected in the official documents. In fact, the WFD itself makes allowances for modifying requirements and time tables; for example, the date for achieving "good status" can be effectively delayed until 2027 (Barreira, 2006). We predict that not only in the Tisza basin, but throughout all of Europe, exemptions will be negotiated as the stringent requirements of WFD collide with the practical, political, and economic realities of the actions needed to meet its ambitious targets and time-tables.

A particularly important issue to clarify for the Tisza basin is the apparent conflict between conventional flood prevention approaches and "good ecological status," since within the WFD, hydromorphological regulation is deemed inconsistent with "good ecological status". Taking the statutory language of WFD literally would seem to require the "re-naturalization" of the Tisza river system: undoing manmade modifications, reversing channelizations, and restoring natural riparian environments. Just such an engineering reversal is recommended by some scholars, who argue that the existing manmade flood control system in the Tisza basin is a failure, and that the re-naturalization of the Tisza and its tributaries is the only promising option (Sendzimir et al., 2008). Yet, the extensive re-naturalization of the region's waterways seems impractical and prohibitively costly, given the scale of existing flood control infrastructure and floodplain development (Kling and 
Szlavik, 2005). What does seem feasible is the improvement of conventional flood control measures in conjunction with some degree of riparian restoration. That combination would require a negotiation to strike an acceptable tradeoff within the Tisza basin planning process which makes some allowance for both conventional flood control engineering and re-naturalization. With the right kind of trade-off, a more ecologically beneficial and effective flood control system could be developed in conjunction with modified goals for the ecological status of waters. Achieving that kind of compromise would advance the policy objectives to improve both surface water quality and flood management in the region - an outcome which would have to be rated a major success for policy-making.

\section{Acknowledgments}

We wish to acknowledge instructive comments from István Pomázi, Balázs Borsos and Ágnes Fülemile. We also appreciate research assistance from Shu-Chuan Chiu. Of course, the usual disclaimer applies: any errors in the article of fact or interpretation are the authors' alone.

\section{Notes}

1 Most basin countries are signatories of international conventions such as the UNECE Convention on the Protection and Use of Trans-boundary Water Courses and International Lakes, signed in Helsinki in 1992, and the Framework Convention on the Protection and Sustainable Development of the Carpathians, signed in Kiev in 2003. Despite these and many other bi- and multi-lateral compacts, a 2004 United Nations assessment noted that there have been relatively small scale environmental improvements, due to poor administrative coordination and weak enforcement.

2 We adopt the convention of spelling tributary names according to spelling of the country at the location in question. Thus, we use the Hungarian spellings "Szamos" and "Maros" to denote the river names at the point they enters the Tisza in Hungary, while using the Romanian names "Someš" and "Mureš" to refer to the upland reaches of these same rivers, located in Romania.

3 We do not include data on economic performance in the region post the recent world-wide global crisis beginning in the fall of 2008.

4 In addition to income, the distribution of assets has widened in the recent period. For example, in the immediate aftermath of the fall of the Soviet Union, state owned farms were broken up and parceled out to small farmers. Many of these relatively unproductive units were bought up by larger scale out-of-region business, interests thus re-concentrating agricultural land - now in the hands of large capitalist land owners (Sendzimir et al., 2008).

5 We don't have direct evidence for the comparison of waster water effluents per unit of output of industrial facilities in the Tisza basin relative to western European plants, but as a general rule, state-owned industrial enterprises during the Soviet period used inputs, including water, inefficiently, due to the absence of economic incentives to economize on input use. That re- 
sulted in greater waste water (and other pollutant discharges) per unit of output for state-owned plants than industrial facilities in the West (Bluffstone and Sterner, 2006).

6 This survey was conducted as part of a pilot project designed to help implement the public participation component of the EU WFD (See Vari et al., 2009).

7 The dissolved oxygen content of waters reflects many environmental parameters besides the level of organic waste pollution, including air pressure, water temperature, the degree of a water's aeration through physical agitation, and the biological activities of plants and animals (photosynthesis and respiration) within the water body. The DO content of water is inversely related to the water's temperature and directly related to its degree of physical aeration, for example. Thus, cooler, highly oxygenated, higher velocity waters in mountainous areas will have relatively high DO concentrations, and contain fish species like trout which are adapted to high DO concentrations. Warmer, slower moving sections of the same river will have lower DO concentrations, and contain more species like carp adapted to handle relatively low oxygen concentrations. There will also be seasonal and diurnal variations of the oxygen content of waters. DO concentrations will be lower in warmer summertime months than during the winter. DO concentrations will increase when water plants photosynthesize and diminish from respiratory activity, which gives natural diurnal variation in DO concentrations on the same stretch of river - higher during the daytime and lower at night.

8 Data in this section are drawn from the ICPDR interim report (ICPDR, 2008). A final report is due by the end of 2009.

9 There is substantial debate in the academic literature about what attributes of policy lead to successful implementation, and there is not a consensus about the premise motivating the implementation approach of EU WFD, i.e., the premise that stakeholder engagement at the local level will facilitate implementation (Kastens and Newig, 2007; Pickvance, 2002 ). However, what is beyond debate is that the implementation of past EU environmental legislation and directives in terms of "on the ground" environmental impact has been spotty (Jordan, 1999). Thus, it is significant that the WFD introduces a regulatory framework utilizing environmental quality standards (EQS) and establishes a monitoring network to measure water quality against these standards. That is, environmental performance will be judged by in situ monitoring, rather than the mere transposition of EU legislation into the national laws of member countries, a traditional metric for implementation in the past (Jordan, 1999).

\section{References}

Analysis of the Tisza River Basin 2007: Initial Step Toward the Tisza River Basin Management Plan - 2009. ICPDR (International Commission for the Protection of the Danube River), 2008. International Commission for the Protection of the Danube River (Vienna).

Barreira, A. (2006) Water Governance at the European Union. Journal of Contemporary Water Research and Education, Vol. 135, 80-85.

Bluffstone, R. and Sterner, T. (2006) Explaining Environmental Management in Central and Eastern Europe. Comparative Economic Studies, Vol. 48, 619-40.

Burnod-Requia, K. (2004) Rapid Environmental Assessment of the Tisza River Basin. United Nations Environment Programme, (Geneva).

CEO (Carpathian Environmental Outlook) (2007) United Nations Environment Programme (Geneva). 
ICPDR (Interational Commission for the Protection of the Danube River Water Quality in the Danube River Basin - 2004) (2007) International Commission for the Protection of the Danube River (Vienna).

Jordan, A. (1999) The Implementation of EU Environmental Policy: A Policy Problem Without Political Solution? Environment and Planning C: Government and Policy, Vol. 17, 69-90.

Kastens, B. and Newig, J. (2007) The Water Framework Directive and Agricultural Nitrate Pollution: Will Great Expectations in Brussels be Dashed in Lower Saxony? European Environment, Vol. 17, 231-46.

Kerekes, S. and Kiss, K. (1998) Hungary's Accession to the EU: Environmental Requirements and Strategies. European Environment, Vol. 8, 161-70.

Kling, Z. and Szlavik, L. (2005) More Room for Flood Waves in the Tisza Basin. In Geophysical Research Abstracts, 7.

Lackenbauer, J. (2004) Catching-Up, Regional Disparities and EU Cohesion Policy: The Case of Hungary. Managing Global Transitions, Vol. 2, No. 2, 123-62.

Lucas, C. (2001) The Baia Mare and Baia Borsa Accidents: Cases of Severe Transboundary Water Pollution. Environmental Policy and Law, Vol. 31, No. 2, 106-11.

Page, B. and Kaika, M. (2003) The EU Water Framework Directive: Part 2. Policy Innovation and the Shifting Choreography of Governance. European Environment, Vol. 13, 328-43.

Pickvance, C. (2002) Settlement Type and Local Government Environmental Policy in Hungary: The Role of Local Economic Structure and Local Government Resources. European Environment, Vol. 12, 90-104.

PRESERVE (Peer REvievs for Sustainable Eco-Region Via Europe), 2009. http://preserve.aer.eu/ about-the-partners/eszak-alfoeld.html.

Sakan, S. et al. (2002) Water Quality Parameters of the Tisza River. Journal of Environmental Protection and Ecology, Vol. 3, No. 4, 828-33.

Sendzimir, J. et al. (2008) Assessing the Resilience Of a River Management Regime: Informal Learning in a Shadow Network in the Tisza River Basin. Ecology and Society, [Online] Vol. 13, No. 1, 11. http://www.ecologyandsociety.org/vol13/iss1/art11

UNEP/OCHA (United Nations Environmental Programme/ Office for the Co-ordination of Humanitarian Affairs). Cyanide Spill at Baia Mare, 2000. Assessment Report, 3.

Vari, A., Ereifej, L. and Zoltán, F. (2009) Implementing the EU Water Framework Directive in Hungary: A pilot project in the Upper-Tisza region. International Journal Risk Assessment and Management, Vol. 12, No. 1, 82-102.

Vujanovic, M. Kilibarda and Jaksic, P. (2002) Tisza River Basin - Past And Future. Journal of Environmental Protection and Ecology, Vol. 3, No. 3, 621-28. 
